\title{
The Precambrian and Lower Paleozoic of the Brunovistulicum (eastern part of the Upper Silesian Block, southern Poland) - the state of the art
}

\author{
Zbigniew BUŁA ${ }^{1}$, Ryszard HABRYN ${ }^{1}$, Monika JACHOWICZ-ZDANOWSKA ${ }^{1, *}$ \\ and Jerzy ŻABA ${ }^{2}$ \\ 1 Polish Geological Institute - National Research Institute, Upper Silesian Branch, Królowej Jadwigi 1, 41-200 Sosnowiec, \\ Poland \\ 2 University of Silesia, Faculty of Earth Sciences, Będzińska 60, 41-200 Sosnowiec, Poland
}

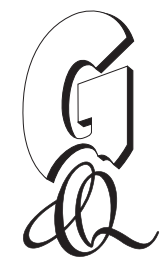

Buła, Z., Habryn, R., Jachowicz-Zdanowska, M., Żaba, J., 2015. The Precambrian and Lower Paleozoic of the Brunovistulicum (eastern part of the Upper Silesian Block, southern Poland) - the state of the art. Geological Quarterly, 59 (1): 123-134, doi: 10.7306/gq.1203

The Precambrian basement and Lower Paleozoic (Cambrian-Ordovician) sedimentary cover in the eastern part of the Upper Silesian Block (Brunovistulicum), known only in boreholes, is presented, and their palaeogeographic, facies and palaeotectonic development is discussed. The former is characterized by a heterogeneous structure that consists of Archean-Lower Proterozoic and Neoproterozoic rocks of different lithologies and origins, and the latter is almost exclusively represented by marine, transitional and terrestrial siliciclastic rocks. In contrast to the neighbouring region of the western part of the Małopolska Block, the siliciclastic sedimentation took place during the Early and Middle Cambrian in this area, however, the Ordovician deposits were encountered in several boreholes and no Silurian rocks have been reported in the northern part of this region. The authors present the most probable model of sedimentation, tectonics and origin of the geological structure of the Lower Paleozoic sedimentary cover in the Upper Silesian Block, define research problems, and justify the need for new drillings. Based on the geological and structural analysis of the depth to the top surface of the Lower Paleozoic, they define the optimal location for three $1500 \mathrm{~m}$ deep boreholes to solve the basic research problems.

Key words: Precambrian basement, Lower Paleozoic sedimentary cover, Upper Silesian Block, Brunovistulicum, southern Poland.

\section{INTRODUCTION}

The Upper Silesian Block, located in southern Poland in Lower and Upper Silesia and western Małopolska (Kotas, 1982, 1985; Buła and Żaba, 2005, 2008; Buła et al., 2008), is part of a larger tectonic unit known as the complex terrane Brunovistulicum (or Brunovistulian). It also includes the Brno Block located in Moravia, the Czech Republic (Dudek, 1980; Kotas, 1982, 1985; Finger et al., 2000; Buła and Żaba, 2005; Żelaźniewicz et al., 2009, 2011). The boundary between the Upper Silesian Block and the Brno Block is marked by the Haná Fault interpreted as the southeastern extension of the Labe Fault (Fig. 1; Buła and Żaba, 2005; Buła et al., 2008 and references therein). The view presented by the authors is different than that expressed by Finger et al. (2000) and Kalvoda et al. (2003) who argued that the northern boundary of the Brno

* Corresponding author, e-mail: monika.jachowicz@pgi.gov.pl Received: January 31, 2014; accepted: September 12, 2014; first published online: November 19, 2014
Block is situated within the Central Basic Belt that separates the Thaya and Slavkov terranes.

The northern part of the Brunovistulicum extends from the Vienna-Brno-Wrocław line in the west to the Odra Fault Zone in the north, and to the Kraków-Lubliniec Fault Zone in the north-east, which adjoins the Małopolska Block (Fig. 1; Buła and Żaba, 2005, 2008; Buła et al., 2008). The western boundary of the Brunovistulicum, at the contact with the Moldanubicum of the Bohemian Massif (Moravo-Silesian Fault Zone), shows a complex geological nature. It is delineated by the Diendorf and Boskovice faults and by the Svojanov, Nyznerov and Strzelin thrusts included in the Moldanubian Thrust Zone (Franke and Żelaźniewicz, 2000; Oberc-Dziedzic et al., 2001. 2003; Buła and Żaba, 2005). The southern part of the Brunovistulicum is the basement of the Outer Carpathians and extends at least to the Peri-Pieniny Fault Zone (Fig. 1).

The Precambrian basement of the Brunovistulicum has been explored by boreholes drilled in the southern, subCarpathian part of this tectonic units in the area between Brno and Kraków. Anchimetamorphic, metamorphic and igneous rocks that constitute the basement locally subcrop at the subCenozoic surface. They are exposed on the surface in the western part of the Brno Block, near Olomouc in several isolated 


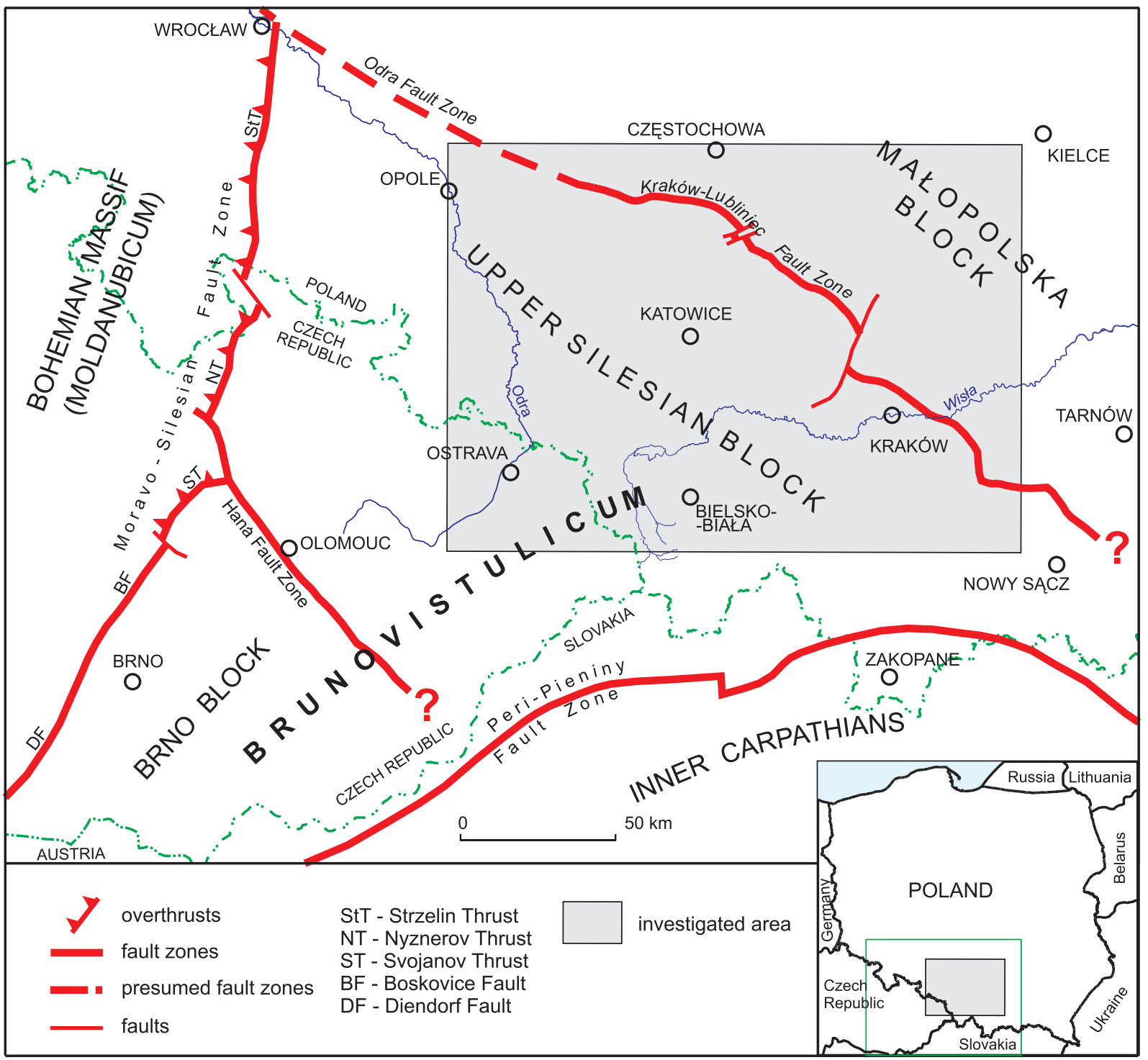

Fig. 1. Tectonic position of Brunovistulicum (after Buła et al., 2008)

outcrops, and in the Jeseníky Massif and the Strzelin Massif (Buła and Żaba, 2005, 2008; Leichmann et al., 2006; Buła et al., 2008; Żelaźniewicz et al., 2009). Over the remaining area, the Precambrian basement of the Brunovistulicum has not been explored yet. In the northwestern part of this tectonic unit, within the Moravo-Silesian Fold and Thrust Belt, the basement is covered with the Variscan metamorphic successions of an accretionary wedge, including Lower Carboniferous flysch deposits attaining several kilometres in thickness (Otava et al., 1994; Kalvoda et al., 2008). In the northeastern part, within the Upper Silesian Foredeep, as we move from the south and south-east towards the north-west, the basement gradually dips underneath a thickening (from a few hundred metres to more than $6 \mathrm{~km}$ ) sedimentary cover of the Cambrian-Ordovician (epiCadomian) structural level and the Variscan structural level. The latter is represented by Lower Devonian clastics (Old Red facies), Middle-Upper Devonian and Lower Carboniferous carbonates, Lower Carboniferous Culm-type siliciclastics and Upper Carboniferous coal-bearing molasse deposits forming the Upper Silesian Coal Basin (USCB).
This paper deals with the present-day state of recognition of the geological structure of the Precambrian basement and the Lower Paleozoic (Cambrian-Ordovician) sedimentary cover in the eastern part of the Upper Silesian Block. This area is situated between the Orłowa-Boguszowice Thrust in the west and the Kraków-Lubliniec Fault Zone in the north-east, and marks the boundary between the Upper Silesian (Brunovistulicum) Block and the Małopolska Block. Against this background, the paper points out to the fundamental, but yet unresolved problems relating to the geological evolution of the above-mentioned rock complexes, and presents possible solutions by drilling new test boreholes.

\section{PRECAMBRIAN BASEMENT}

In the eastern part of the Upper Silesian Block, the Precambrian basement is well-explored only in its southern portion. Crystalline and anchimetamorphic rocks, which constitute the 
basement, have been drilled by 22 boreholes in the area located to the south of the Pszczyna-Zator-Kraków line, where they underlie different age deposits representing the Lower Cambrian, Jurassic and Miocene (Fig. 2; Moryc and Heflik, 1998; Buła, 2000; Buła and Żaba, 2005). In this part of the Upper Silesian Block, the Precambrian basement is represented by three zonally arranged rock complexes, different in terms of origin and age (Buła and Żaba, 2005, 2008; Żelaźniewicz et al., 2009). They were distinguished and defined on the basis of geophysical data (gravimetry, magnetometry, seismicity), lithology, and determinations of absolute age carried out on zircons extracted from rock samples collected from the Kęty 8, Roztropice 3, Roczyny 3, Łodygowice IG 1, Ślemień 1, Lachowice 4 and Rzeszotary 2 boreholes (SHRIMP), as well as

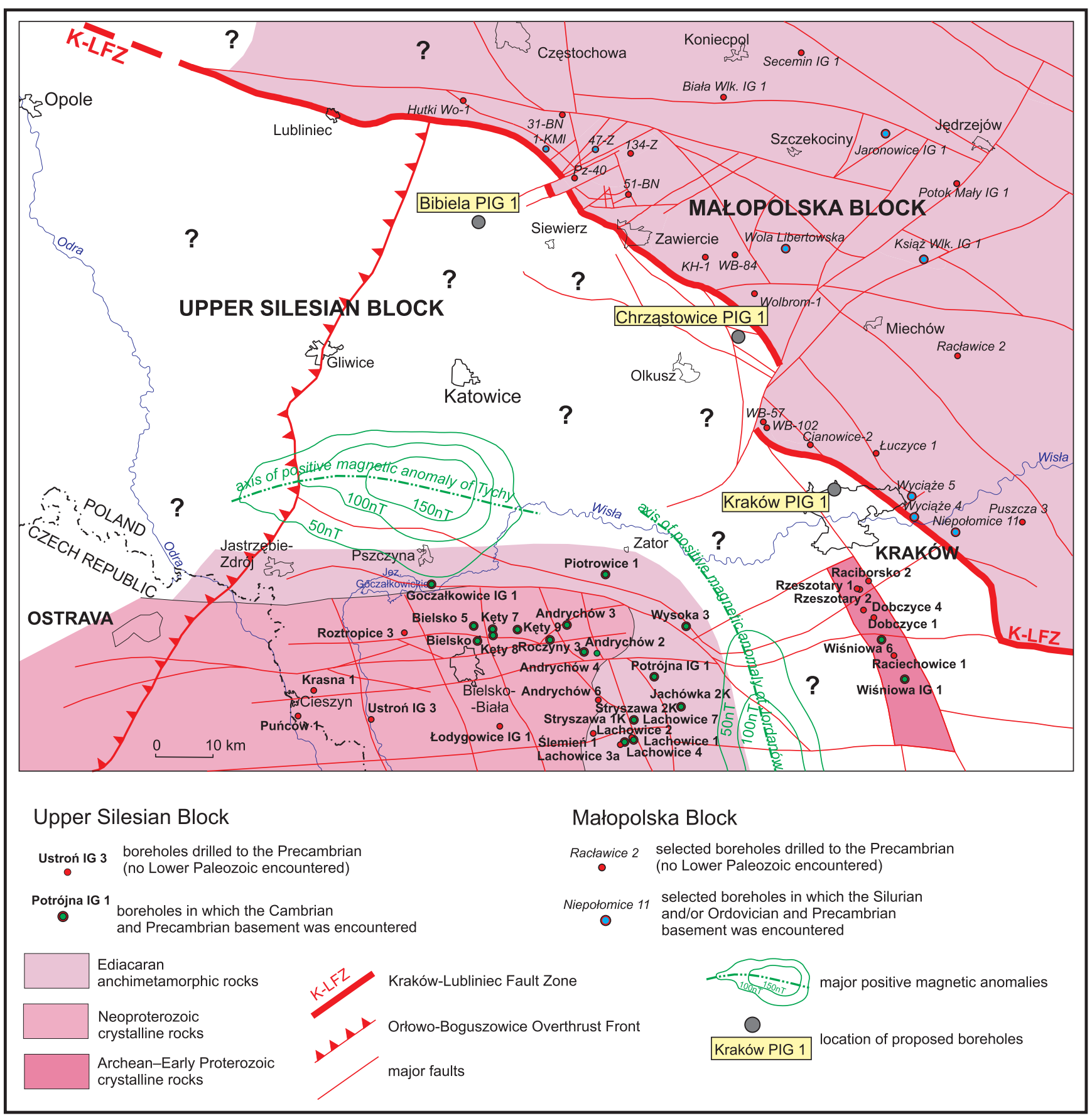

Fig. 2. Geological map (without formations younger than the Ediacaran) (after Buła and Żaba, 2005; Buła and Habryn, 2008; modified) 
on muscovite from Krasna 1 (K-Ar). A comparative dating analysis of lithologically and petrographically similar rocks that were found in neighbouring boreholes, was also used.

From the south and west towards the north and east, there are the following complexes (Fig. 2):

1 - complex of Neoproterozoic (660-556 Ma) crystalline (metamorphic and igneous) rocks found in the Cieszyn-Żywiec-Bielsko-Biała-Andrychów-Kęty area. The rocks continue to the south-west as far as the Brno region in the Czech Republic;

2 - complex of Ediacaran anchimetamorphic flysch-type siliciclastics, strongly tectonically deformed and locally phyllitized. This rock complex has been examined in a narrow belt stretching from Goczałkowice through Piotrowice-Wysoka-Potrójna to the Lachowice area. On the south and west, it adjoins the above-mentioned complex of Neoproterozoic crystalline rocks;

3 - complex of Paleoproterozoic $(2.0 \mathrm{Ga}$ ) crystalline (metamorphic) rocks with inherited Archean elements of $2.7 \mathrm{Ga}$ age. These rocks have been examined in the Rzeszotary-Wiśniowa region (south of Kraków) within a subsouthern structural element - the Rzeszotary Horst.

Previous lithological, petrographic and radiometric studies of Precambrian basement rocks in the eastern part of the Upper Silesian Block prove its complex, heterogeneous structure. Buła and Żaba $(2005,2008)$ and Żelaźniewicz et al. (2009) relate the tectonometamorphic evolution of Neoproterozoic crystalline and anchimetamorphic rocks of complexes 1 and 2 to the Cadomian (Cadomian-Avalonian) tectonic processes. However, in their opinion, the Neoproterozoic crystalline rocks (complex 2) represent the inner part of the Cadomian orogen (Cadomian internides), and the Ediacaran anchimetamorphic flysch-type siliciclastics (complex 2) form its outer part (Cadomian externides). According to those authors, the crystalline rocks in the Rzeszotary Horst (complex 3 ), which formed as a result of Archean-Early Proterozoic tectonic and metamorphic processes, are part of the Cadomian orogen foreland.

The Neoproterozoic crystalline and anchimetamorphic rocks (complexes 1 and 2) have been assigned by Żelaźniewicz et al. (2009) to the Slavkov Terrane, while the Archean-Lower Proterozoic crystalline rocks (complex 3 ) - to the Rzeszotary Terrane. The boundary between the two different age crustal fragments, constituting the Precambrian basement of the eastern part of the Upper Silesian Block, is not known.

Complexity of the geological structure of the Precambrian basement, observed in this part of the Upper Silesian Block, makes it difficult to predict its characteristics in the remaining, hitherto unexplored part of this tectonic unit comprising an area situated north and east of the Goczałkowice-Piotrowice-Wysoka-Potrójna line as far as the Kraków-Lubliniec Fault Zone (Fig. 2).

The variability of the geological structure of the Precambrian basement in the eastern part of the Upper Silesian Block was previously assumed by Kotas (1972, 1982, 1985), based mostly on the results of geophysical magnetic surveys. Using those results, he presented a number of options regarding the internal structure of the Precambrian basement, and distinguished within the basement a number of structural elements defined as microplates or blocks. A common characteristic feature of the Precambrian basement subdivision schemes, proposed by Kotas $(1972,1982,1985)$, is a similar direction of the individual structural elements that run longitudinally (W-E) in the western part, and change their direction to submeridional (NNW-SSE) further to the east. Kotas (1972) drew special attention to the two large, merging positive magnetic anomalies of Jordanów and Tychy, clearly marked in the eastern part of the Upper Silesian Block. Kotas (1985) linked their origin with alkaline magmatism (the presence of diabases) that developed within the Precambrian basement along the axis of these anomalies, and/or with metamorphosed ophiolites. A similar origin of the Jordanów and Tychy anomalies was proposed by Bojdys et al. (1982), who suggested their origin due to the presence of gabbros, excluding the possibility of any occurrence of ultrabasites.

Taking into account the current state of knowledge on the Precambrian basement in the eastern part of the Upper Silesian Block, Buła and Żaba (2008) assumed that the axis of the Jordanów and Tychy positive magnetic anomalies, whose origin is associated with unknown alkaline magmatic rocks (they are beyond the reach of so-far drilled deep boreholes; Kotas, 1972; Bojdys et al., 1982), determines the course of the contact zone (tectonic suture) between two crustal elements forming the Precambrian basement in this area: the Archean-Lower Proterozoic element and the Neoproterozoic (Cadomian) element. According to Żelaźniewicz et al. (2009), the contact zone runs between the Rzeszotary and Slavkov terranes. The above-discussed view, postulated by Buła and Żaba (2008), is supported by the fact (Fig. 2) that Neoproterozoic (Cadomian) crystalline and anchimetamorphic rocks of the Slavkov Terrane are surrounded on the north, north-east and east by a belt of the merged Jordanów and Tychy anomalies. On the eastern side of the Jordanów anomaly, there are Archean-Lower Proterozoic crystalline rocks of the Rzeszotary Terrane.

According to Buła and Żaba (2008), the Precambrian basement of the Upper Silesian Block, in its unexplored part situated between the axis of the Jordanów and Tychy positive magnetic anomalies and the Kraków-Lubliniec Fault Zone constituting the boundary between the Upper Silesian and Małopolska blocks, is composed of the Archean-Paleoproterozoic crystalline rocks (complex 3).

Another version of the geological structure of the Precambrian basement in this part of the Upper Silesian Block is postulated in Żelaźniewicz et al. (2009) by its leading author, who assumes the continuation of the Ediacaran anchimetamorphic flysch-type siliciclastics (complex 2) from the Goczałkowice-Piotrowice-Wysoka-Potrójna-Lachowice region towards the north and north-east to the Kraków-Lubliniec Fault Zone. Żelaźniewicz et al. (2009) are of the opinion that Ediacaran flysch of the Upper Silesian Block is in contact along this fault zone with coeval and litho-tectonically similar flysch deposits of the Małopolska Block (Fig. 2). The Ediacaran flysch of the Małopolska Block underlies deposits of different ages: Paleozoic (from Ordovician to Permian), Mesozoic (Triassic and Jurassic) and Cenozoic (Miocene) (Buła and Habryn, 2008).

Explanation of the above-mentioned different views on the geological structure of yet unknown part of the Precambrian basement in the eastern part of the Upper Silesian Block requires further drilling exploration. 


\section{LOWER PALEOZOIC SEDIMENTARY COVER}

The Lower Paleozoic sedimentary cover in the eastern part of the Upper Silesian Block is represented by non-metamorphosed Cambrian siliciclastic and Ordovician siliciclastic-carbonate rocks. The degree of exploration of these rocks is very uneven and generally weak (Fig. 3). It is not only due to a highly diverse and mostly considerable depth to the rocks, but also results from the lack of adequately deep boreholes designed appropriately to their structure and thickness.

Rocks of the Lower Paleozoic sedimentary cover, represented by Lower Cambrian siliciclastics, have been more thoroughly explored in the southern portion of the eastern part of the Upper Silesian Block, in the area situated south of Jastrzębie-Zdrój-Pszczyna-Zator-Kraków. They were encountered in 32 deep boreholes $(1,500-5,000 \mathrm{~m})$ - including most of those that have reached the Precambrian basement (see Figs. 2 and 3).

Cambrian deposits of this area, of different thicknesses from several to more than $1,400 \mathrm{~m}$, are overlain directly by the Devonian (mainly Lower Devonian) or Jurassic rocks, and they rest discordantly upon genetically diverse Precambrian rocks of different ages (Buła and Jachowicz, 1996; Buła, 2000; Buła and Żaba, 2005; Pacześna, 2005).

The Cambrian rocks, similar in lithology and facies to those observed in the above-mentioned part of the Upper Silesian Block, have also been found in its easternmost margin adjacent to the Kraków-Lubliniec Fault Zone, in the area between Siewierz, Olkusz and Kraków (Fig. 3). Lower Cambrian sections of various thickness (from $30 \mathrm{~m}$ to $200 \mathrm{~m}$ ) were drilled in that area in twelve shallow boreholes with depths of $120-600 \mathrm{~m}$, and the two deep boreholes of Klucze 1 and Ogrodzieniec 2-2,100 m and 2,006 m deep, respectively (Buła, 2000; Buła and Habryn, 2010; Habryn et al., 2014). In this region, the Lower Cambrian strata are overlain directly by the Devonian, Triassic and Jurassic deposits.

The Cambrian age of siliciclastic rocks that underlie the Devonian, Triassic or Jurassic in the above-mentioned areas of the eastern part of the Upper Silesian Block, has been proved by palynological studies (acritarch determinations) conducted in 18 boreholes (Buła and Jachowicz, 1996; JachowiczZdanowska, 2010, 2013), and on the basis of trilobites in the Goczałkowice IG 1 borehole (Orłowski, 1975). According to the new stratigraphic scheme of the Cambrian system (Gradstein et al., 2012), these are Terreneuvian and Series 2 deposits (Fig. 4; Jachowicz-Zdanowska, 2013).

Two main lithostratigraphic units have been identified and defined in the studied Lower Cambrian sections: the Borzęta Formation and the Goczałkowice Formation (Buła and Jachowicz, 1996; Buła, 2000), which have been divided into lowerorder lithostratigraphic units - members (Fig. 4; Buła, 2000; Buła and Żaba, 2005; Buła and Habryn, 2010). The Borzęta Formation consists of three members: Myślenice Claystones Member, Osieczany Mudstones Member and Rajbrot Sandstones Member, while the Goczałkowice Formation is represented by four subunits: Mogilany Scolithos Sandstones Member, Głogoczów Bioturbated Sandstones Member, Pszczyna Mudstones with Trilobites Member and Jarząbkowice claystones (informal unit).
The Lower Cambrian clastic deposits from this part of the Upper Silesian Block, often containing ichnotaxonomically and ethologically diverse trace fossil associations, are characterized by high facies variability. They were deposited in terrestrial (braided rivers and alluvial fans), transitional (fan and braided deltas), and marine (shoreface and offshore) environments (Pacześna and Poprawa, 2001; Pacześna, 2005, 2014). Distinct lithological and facies variability is observed mainly in the vertical section of Lower Cambrian deposits. The Borzęta Formation deposits, representing a regressive lithological-facies sequence, were deposited in a gradually shallowing marine basin (Buła, 2000). The Myślenice Member deposits developed in the lower offshore zone, the Osieczany Mudstone Member deposits accumulated in the distal and proximal offshore zone, and the deposition of the Rajbrot Sandstones Member occurred in the shoreface zone (Pacześna, 2014). The Goczałkowice Formation deposits show the characteristic features of a transgressive lithological-facies sequence (Buła, 2000). This formation starts with coarseclastic deposits of the Mogilany Scolithos Sandstones Member, which were initially deposited in terrestrial environments (mainly alluvial sediments) and later in terrestrial-shoreface environments - i.e. at the mouths of deltas and in the upper shoreface zone (Pacześna, 2005). Deposits representing the upper part of this formation accumulated in a marine environment. The Głogoczów Bioturbated Sandstones Member deposits accumulated in the upper and middle shoreface, the Pszczyna Mudstones with Trilobites Member - in the lower shoreface and upper offshore zone (Pacześna, 2005), and the Jarząbkowice claystones - probably in the lower offshore environment. It should be emphasized that the Goczałkowice Formation deposits are characterized by a considerable lateral extent. Their stratigraphic and lithologic-facies equivalents occur in the Czech Republic, in the Brno Block (Buła et al., 1997; Jachowicz and Přichystal, 1997; Vavrdová et al., 2003; Jachowicz-Zdanowska, 2013).

A $95 \mathrm{~m}$ thick partial section of the Middle Cambrian (Series 3) clastics from the eastern part of the Upper Silesian Block was examined so far only in the Sosnowiec IG 1 borehole at a depth of 3156.0-3442.6 m (Fig. 3). These deposits underlie the Lower Devonian, and their stratigraphic position is defined by palynological data (Buła and Jachowicz, 1996; Jachowicz-Zdanowska, 2013). They have been distinguished as the Sosnowiec Formation (Fig. 4; Buła, 2000). The upper part of the formation (with a thickness of about $177 \mathrm{~m}$ ) is represented by fine-grained siltstones and sandstones. The lower part (unpierced in this borehole) is composed of an $18 \mathrm{~m}$ thick complex of variably grained sandstones with admixture of fine gravel, which has been distinguished as the Radocha Member of variably grained sandstones and pebbles with fine gravel (Kowalczewski, 1990; Buła, 2000).

Deposits representing the upper part of the Sosnowiec Formation accumulated in a marine environment, as evidenced by, among others, the presence of remains of inarticulate brachiopods and acritarchs (Biernat and Baliński, 1973; Jachowicz-Zdanowska, 2013), probably in the lower shoreface and upper offshore. Depositional environment of these variably grained and gravelly sandstones of the Radocha Member has not yet been determined; perhaps they developed in a transitional, terrestrial-marginal marine environment. The Middle Cambrian deposits in the Sosnowiec IG 1 borehole 


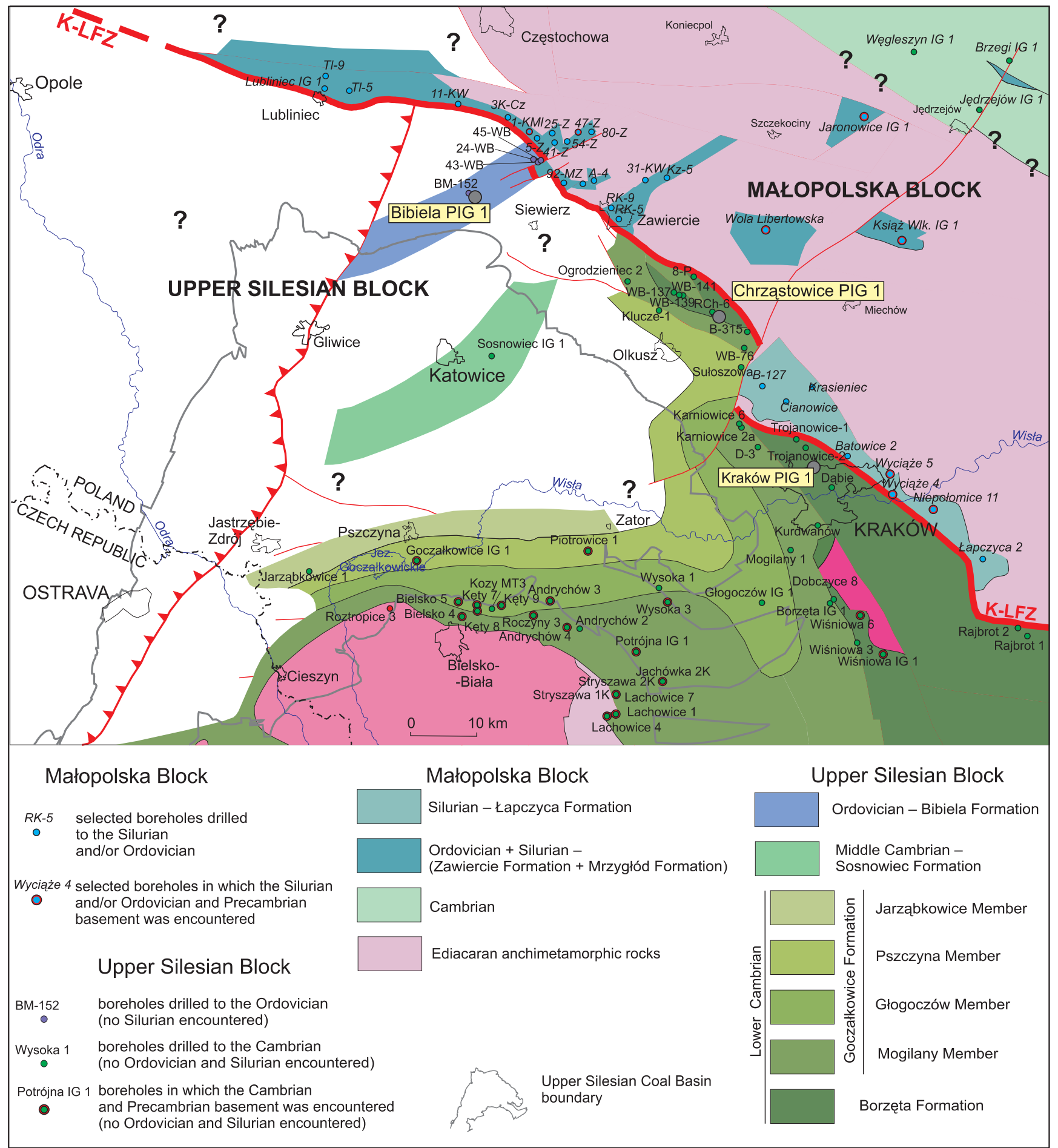

Fig. 3. Geological map (without formations younger than the Silurian) (after Buła and Żaba, 2005; Buła and Habryn, 2008; modified) 


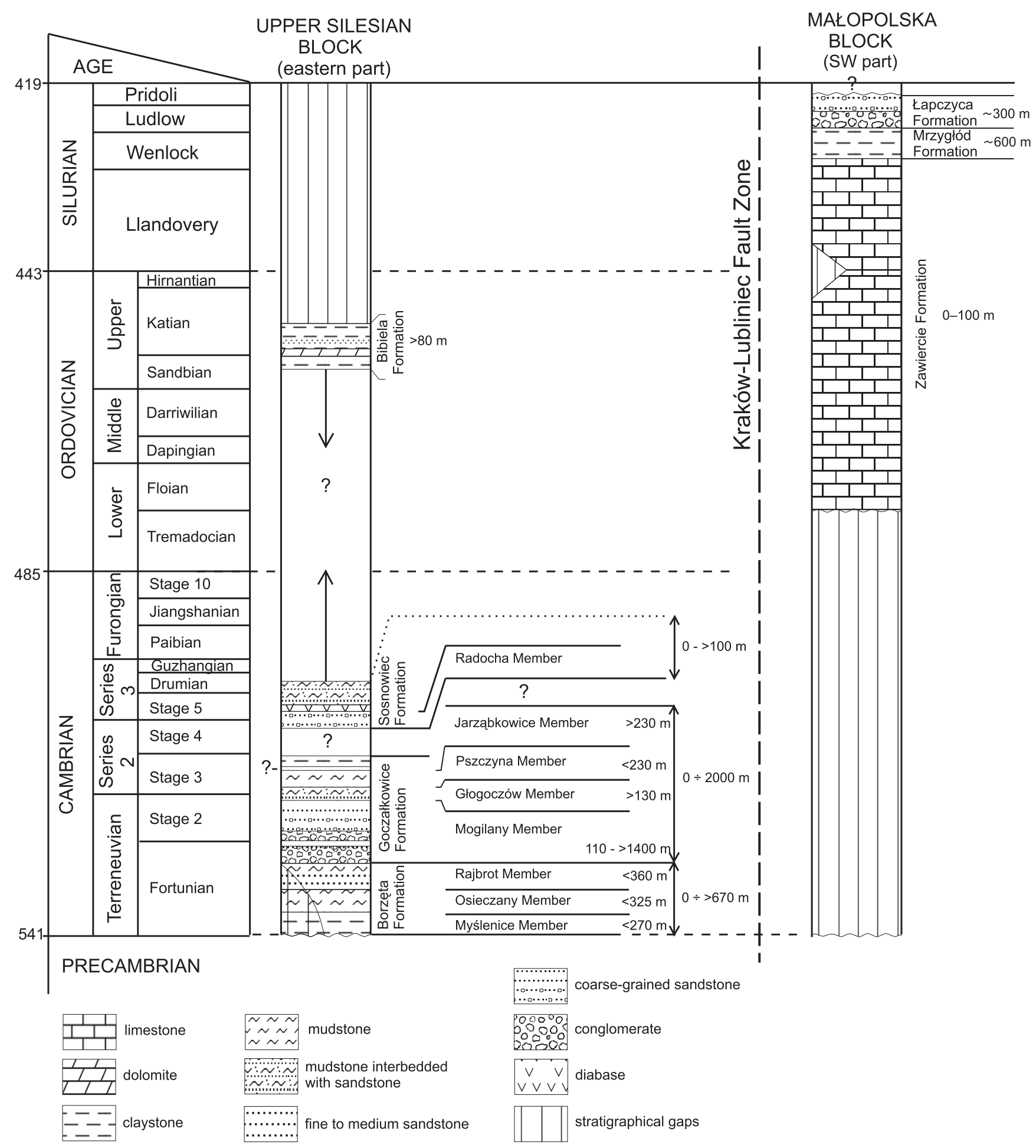

Fig. 4. Lower Paleozoic schematic stratigraphic sections of the eastern part of the Upper Silesian Block and the southwestern part of the Małopolska Block (after Buła, 2000; Buła and Żaba, 2005; slightly modified) 
are cosscut by an igneous intrusion with the apparent thickness of $92 \mathrm{~m}$.

The Lower Paleozoic sedimentary cover in the eastern part of the Upper Silesian Block also includes Ordovician marine siliciclastic-carbonate deposits, whose fragmentary sections, 75 to $102 \mathrm{~m}$ in length, occur under the Devonian or Triassic in four shallow boreholes (300-650 m deep): BM-152, 24-WB, 43-WB and 45-WB, situated north of the Sosnowiec-Siewierz line (Fig. 3; Buła, 2000; Jachowicz, 2005). Ordovician marine deposits of this area, stratigraphic position (Darriwilian-Sandbian/Katian) of which is determined based on conodonts (Siewniak-Madej and Jeziorowska, 1978), acritarchs (Jachowicz in Gładysz et al., 1990; Buła and Jachowicz, 1996; Jachowicz, 2005) and brachiopods (Piekarski et al., 1985), are included in the Bibiela Formation (Fig. 4; Buła, 2000) represented by dark grey and celadon-grey, mostly silicified clays (rare mudstones). The rocks are accompanied by thin interbeds of light grey fine-grained quartz sandstones and grey silicified dolomites.

The current state of knowledge and results of research on the Paleozoic deposits in the eastern part of the Upper Silesian Block undoubtedly reveal a number of unresolved problems relating to the history of the sedimentary development on one hand, and on the other hand they allow specifying - to a limited extent - the accuracy of the tectonic constraints on their deposition.

The results of stratigraphic investigations of the Cambrian and Ordovician in the study area clearly indicate some gaps in the knowledge on their sections (Fig. 4; Buła and Jachowicz, 1996; Buła, 2000; Jachowicz, 2005; Jachowicz-Zdanowska, 2013). There are no data on the Lower Cambrian (Goczałkowice Formation)/Middle Cambrian (Sosnowiec Formation) transition deposits. The unexplored deposits span the section between the lower Middle Cambrian (Sosnowiec Formation) and the Upper Ordovician (Bibiela Formation). Therefore, it is impossible to reconstruct the depositional development during the period from the late Early Cambrian through the Early Ordovician. Among the unresolved issues are the following:

- did the Cambrian deposits develop in sedimentary continuity with the Ordovician, or there are stratigraphic (sedimentary, erosional) gaps and tectonic unconformities in the sections?,

- did Upper Cambrian deposits accumulate at all?

since they have not been encountered in any of the previously drilled boreholes.

A distinctive, clearly marked feature of the Paleozoic deposits (usually underlying the Devonian) from this part of the Upper Silesian Block is their zonal pattern (Fig. 3). It is expressed in the fact that progressively younger Lower Paleozoic deposits subcrop beneath the Devonian surface when moving from the south-east and south to the north-west and north - from Early Cambrian (Terreneuvian) through Ordovician. The reason for the zoning is interpreted by Buła (2000) and Buła and Żaba (2005) as being the result of migration of depocentres in the Early Paleozoic basin of the Upper Silesian Block, especially well-manifested after the Early Cambrian: in the Middle Cambrian, Ordovician and probably even later - in the Silurian. The possibility of deposition during the Silurian in the western part of the Upper Silesian Block is suggested by the presence of rocks representing this system, found in an allochthonous position near Stinava in the Brno Block (Czech Republic; see Buła and Żaba, 2005 and references therein).

The earlier, Early Cambrian stage of depositional development of the Early Paleozoic basin in the Upper Silesian Block was also characterized by a zonal pattern of depocentres. The distribution of the Lower Cambrian Borzęta Formation deposits, representing a regressive lithological-facies sequence, indicates that they were deposited only in the easternmost, marginal part of the Upper Silesian Block adjacent to the KrakówLubliniec Fault Zone (Figs. 2 and 3). Stratigraphic and lithofacies equivalents of the formation have not been found in any of the boreholes that reached Precambrian rocks in the area situated to the west of the Lachowice-Potrójna-Wysoka line.

Precambrian rocks of this area are directly overlain by a younger Lower Cambrian lithostratigraphic unit - the Goczałkowice Formation. Deposits of this formation, representing a transgressive lithological-facies sequence and overstepping the Borzeta Formation deposits, are characterized by a wide extent in the Upper Silesian Block, as well as by the presence of their stratigraphic and lithologic-facies equivalents also in the Brno Block. In the eastern part of the Upper Silesian Block, the thickness of the Goczałkowice Formation increases from the south and west towards the east and north. To the east, the thickness of the lower member of the formation - the Mogilany Scolithos Sandstones Member - is many times greater: from about $100 \mathrm{~m}$ to over $1,400 \mathrm{~m}$. The maximum thickness of the member was found in the Ogrodzieniec $2(800 \mathrm{~m})$, Mogilany $1(1,400 \mathrm{~m})$ and Głogoczów IG $1(1,200 \mathrm{~m})$ boreholes (Fig. 3), but the deposits have not been pierced.

At this point, we should mention the lack of Cambrian deposits in the southwestern edge of the Małopolska Block, presently adjoining the Upper Silesian Block along the KrakówLubliniec Fault Zone (Figs. 2 and 3). The Ediacaran rocks are directly overlain in this area by Ordovician or younger deposits (Silurian through Miocene; Buła and Żaba, 2005; Buła and Habryn, 2008). According to Buła and Habryn (2011), this part of the Małopolska Block was an eroded land area in Cambrian times as a result of Cadomian uplifting movements.

Poprawa (2006) carried out a one-dimensional analysis of tectonic subsidence and deposition rate of Lower and Middle Cambrian siliciclastic deposits in the Upper Silesian Block based on data from 10 boreholes. He has shown varied and generally high subsidence and deposition rates up to about $80 \mathrm{~m} / \mathrm{My}$ and up to about $180-200 \mathrm{~m} / \mathrm{My}$, respectively. The subsidence and deposition rates increase towards the northeastern and eastern edge of the Upper Silesian Block. During the deposition of Cambrian sediments, a single phase of intense tectonic subsidence was clearly marked. Poprawa (2006), bearing in mind the incomplete knowledge on the nature of the Cambrian tectonic subsidence and deposition rates, as well as the directions of thickness changes of the deposits, assumed two alternative models of the Cambrian basin development in the Upper Silesian Block:

- as a flexure-related collisional foredeep,

- as a post-orogenic gravity-induced collapse basin.

As pointed out by him, none of these models is fully confirmed at this stage of knowledge of the Cambrian and Precambrian successions. 
It should be noted that Poprawa (2006), providing the characteristics of geotectonic mechanisms of the Cambrian basin development in the Upper Silesian Block, did not take into account the heterogeneity and complexity of the geological structure of the Precambrian basement, which is discussed in Buła and Żaba (2005) and Żelaźniewicz et al. (2009) as well as in this paper. There is a high probability that the individual structural elements of the basement were variably affected by tectonic (uplifting or downdropping) movements during the collisional (as assumed by Poprawa, 2006) development of the Cambrian basin. This may have resulted both in the observed variations in the subsidence and deposition rates of the Lower Cambrian sediments, and in the migration of depocentres.

Relationships between the geological structure of the Precambrian basement and the characteristic features of the development of Lower Cambrian deposits were pointed out by Buła and Habryn (2010), who noted that, e.g., the Borzęta Formation deposits are limited only to the area where the Precambrian basement is composed of Archean-Lower Proterozoic rocks of the Rzeszotary Terrane. The Goczałkowice Formation is thinnest in the Slavkov Terrane composed of Neoproterozoic rocks. The Mogilany Scolithos Sandstones Member, which is the lower member of the Goczałkowice Formation, attains the maximum thickness in the contact zone between the Rzeszotary and Slavkov terranes. The age of these sediments, correlated with the Platysolenites Zone, was documented so far only in the Brno Block (Vavrdová et al., 2003; JachowiczZdanowska, 2013)

\section{IMPLICATIONS FOR THE FUTURE}

The current state of knowledge on Precambrian and Paleozoic rocks in the eastern part of the Upper Silesian Block, as is clear from the above-presented considerations, significantly limits a reliable interpretation of their sedimentary-diastrophic development. Many of the issues regarding this problem remain hypothetical. The problems and controversial views, presented in the previous chapters of this paper, can be resolved and verified (at least partially) by properly planned drilling exploration to examine the Precambrian and Lower Paleozoic succession.

The possibility of drilling into Precambrian and Paleozoic rocks in the eastern part of the Upper Silesian Block is limited primarily because they rest at considerable depths under a variably thick cover of Devonian-Carboniferous, Permian-Mesozoic and Cenozoic deposits (including flysch deposits of the Outer Carpathians).

The top surface of these deposits is characterized by very high relief variations from $170 \mathrm{~m}$ a.s.l. to $6,000 \mathrm{~m}$ b.s.l. It is illustrated on the structural map of the top of Precambrian and Lower Paleozoic formations (Fig. 5). Based on available cartographic materials (Buła and Kotas, 1994; Jureczka et al., 2005; Buła and Habryn, 2008), we used the principle of extrapolation "into the depths" with the method of positive superposition. Also, the main zones of discontinuities such as faults and overthrusts with their slips and dips appropriately extrapolated "into the depths", were adopted after the above-mentioned authors.

There is a clear trend of gradual declining towards a deep depression, the centre of which is located in the Żory-Orzesze region. The uneven trend in the decline of this surface (to more than $6,000 \mathrm{~m}$ b.s.I.) is also observed in the area located to the south of Kraków. This is the result of intense faulting of the Paleozoic deposits by high-amplitude faults (even over 1,000 m), and by their gradual plunging under the Outer Carpathian flysch units that were thrust from the south. The maximum elevation of this surface is observed in the marginal part of the Upper Silesian Block, directly adjacent to the KrakówLubliniec Fault Zone, where the Lower Paleozoic deposits locally subcrop at the sub-Mesozoic surface. The top surface of the Precambrian-Lower Paleozoic succession shows a number of lower-order elevated or downthrown structural elements, displaced by faults of different amplitudes. Morphostructural elements, manifested on the top surface of the Precambrian-Lower Paleozoic succession, reflect Precambrian and Paleozoic tectonic structures (such as anticlines, synclines and horsts). Deposits of those ages subcrop at the sub-Permian-Mesozoic and sub-Cenozoic surfaces in this part of the Upper Silesian Block (e.g., Buła et al., 2008)

Taking into account (1) the current state of drilling exploration of the Precambrian and Lower Paleozoic succession, (2) so-far unresolved issues regarding its sedimentary-diastrophic development, as well as (3) the relief (structure) and depth to its top surface, it is proposed to drill three fully cored boreholes to a planned total depth of $1,500 \mathrm{~m}( \pm 10 \%)$. The main objective of these boreholes is to explore the hitherto unknown sections of the Precambrian and Lower Paleozoic rocks in the eastern edge of the Upper Silesian Block. The pre-determined location (Figs. 2, 3 and 5) and predicted sections of the planned boreholes are as follows:

1. Bibiela PIG 1 borehole, located approximately $12 \mathrm{~km} \mathrm{NW}$ of Siewierz, should be drilled near the BM-152 borehole, in which the Devonian deposits are underlain at a depth of 248.6-375.6 $\mathrm{m}$ by palaeontologically proven Ordovician rocks included in the Bibiela Formation (Buła, 2000; Jachowicz, 2005). The intended purpose of this drilling is to penetrate and explore the full Ordovician section and the topmost Cambrian series representing the Middle Cambrian and, maybe, the Upper Cambrian, and to reach the topmost part the Lower Cambrian section (about $200 \mathrm{~m}$ ).

2. Chrzastowice PIG 1 borehole, located near the Chrzastowice Rch-6 borehole approximately $10 \mathrm{~km}$ from Olkusz, in which the Triassic is underlain at a depth of 177.0-292.2 m by palaeontologically proven part of the Lower Cambrian (Terreneuvian) section representing the Borzęta Formation (Buła and Habryn, 2010; Jachowicz-Zdanowska, 2010, 2013). The objective of this borehole is to pierce and examine the lower part of the Lower Cambrian section and to reach the Precambrian rocks of unknown origin and age in this area.

3. Kraków PIG 1 borehole, located on the northern outskirts of Kraków near the Trojanowice 1 borehole, in which the Jurassic is underlain at a depth of 206-237 m by part of the Lower Cambrian section representing the Borzęta Formation (Buła and Jachowicz, 1996; Buła, 2000; Jachowicz-Zdanowska, $2010,2013)$. The purpose of this borehole is also to examine 


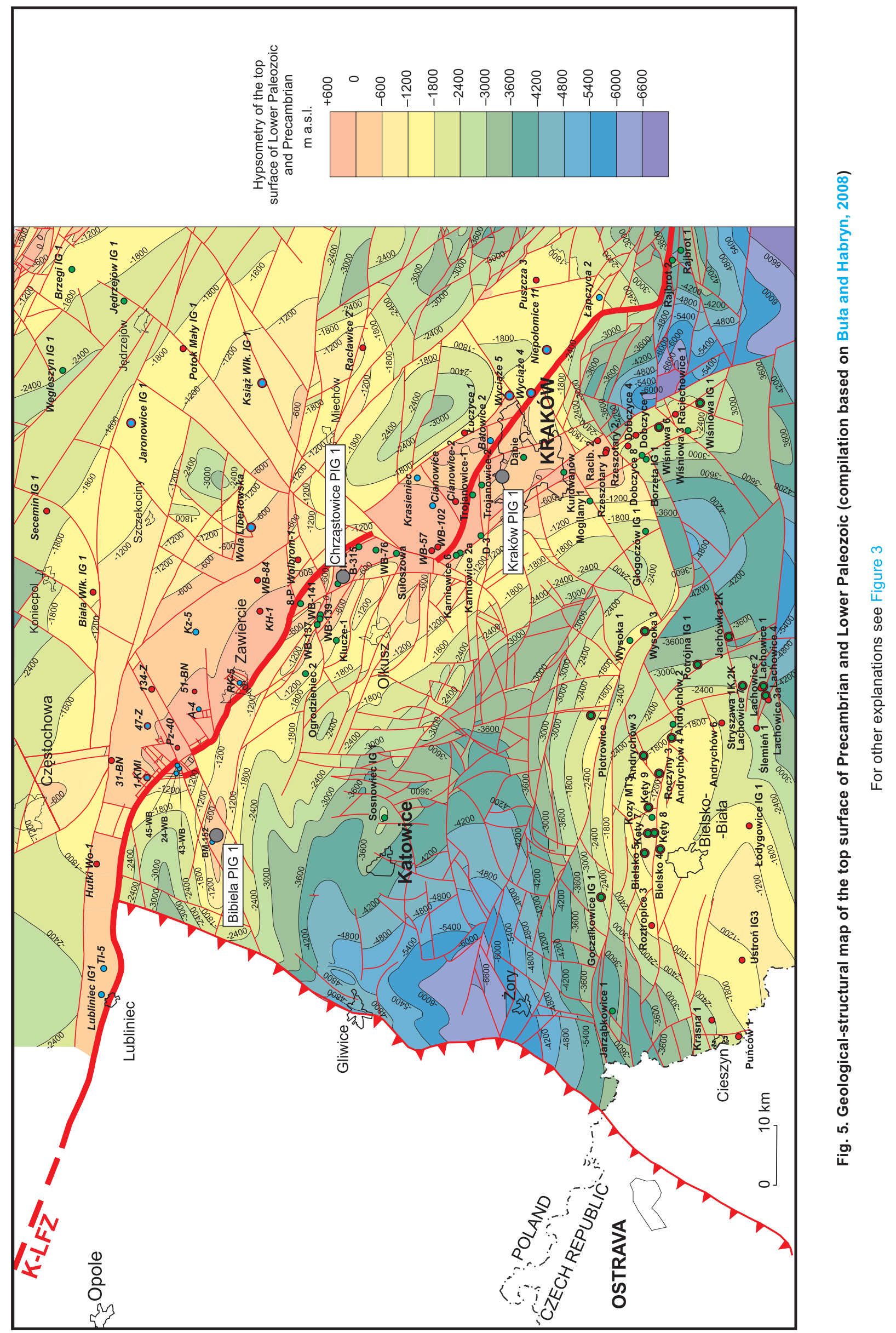


the bottom section of the Lower Cambrian (Terreneuvian) and to reach the Precambrian that may be represented in this area by metamorphic rocks, lithotectonically similar to the ArcheanLower Proterozoic metamorphic rocks found in the southern part of the Rzeszotary Horst (Buła and Żaba, 2005; Żelaźniewicz et al., 2009).
Acknowledgements. The authors thank the reviewers J. Hladil, J. Kalvoda, J. Pacześna and the scientific editor T.M. Peryt for their constructive reviews, comments and suggestions which helped to improve the scientific level of this paper.

\section{REFERENCES}

Biernat, G., Baliński, A., 1973. Fauna z otworów wiertniczych Sosnowiec IG-1 i Goczałkowice IG-1 (Stromatoporoidea, Tabulata, Brachiopoda i Trilobita) (in Polish). Kwartalnik Geologiczny, 17 (3): 629-630.

Bojdys, G., Bujnowski, W., Karaczun, K., Lemberger, M., 1982. Interpretation of gravimetric and magnetic investigations in the Upper Silesian Coal Basin (in Polish with English summary). Biuletyn Instytutu Geologicznego, 333: 61-90.

Buła, Z., 2000. The Lower Palaeozoic of the Upper Silesia and West Małopolska (in Polish with English summary). Prace Państwowego Instytutu Geologicznego, 171: 1-63.

Buła, Z., Habryn R., eds., 2008. Geological-structural atlas of the Palaeozoic basement of the Outer Carpathians and Carpathian Foredeep. Państwowy Instytut Geologiczny, Warszawa.

Buła, Z., Habryn, R., 2010. Precambrian and Paleozoic geology of Cracow region. In: Materiały Konferencji - „Prekambr i paleozoik regionu krakowskiego" (in Polish). Kraków, listopad 2010. Państwowy Instytut Geologiczny - Państwowy Instytut Badawczy, Warszawa: 7-39.

Buła, Z., Habryn, R., 2011. Precambrian and Palaeozoic basement of the Carpathian Foredeep and the adjacent Outer Carpathians (SE Poland and western Ukraine). Annales Societatis Geologorum Poloniae, 81: 221-239.

Buła, Z., Jachowicz, M., 1996. The Lower Paleozoic sediments in the Upper Silesian Block. Geological Quarterly, 40 (3): 299-336.

Buła, Z., Kotas, A., eds., 1994. Geological atlas of the Upper Silesian Coal Basin, part III. Structural-geological maps 1:100 00. Państwowy Instytut Geologiczny, Warszawa.

Buła, Z., Żaba, J., 2005. Pozycja tektoniczna Górnośląskiego Zagłębia Węglowego na tle prekambryjskiego i dolnopaleozoicznego podłoża (in Polish). Przewodnik 76 Zjazdu Polskiego Towarzystwa Geologicznego, Rudy k/Rybnika: 14-42. Warszawa.

Buła, Z., Żaba, J., 2008. Structure of the Precambrian basement of the eastern part of the Upper Silesia block (Brunovistulicum) (in Polish with English suumary). Przegląd Geologiczny, 56: 473-480.

Buła, Z., Jachowicz, M., Přichystal, A.J., 1997. Lower Paleozoic deposits of the Brunovistulicum. Terra Nostra, 11: 32-38.

Buła, Z., Żaba, J., Habryn, R., 2008. Tectonic subdivision of Poland: southern Poland (Upper Silesian Block and Małopolska Block) (in Polish with English summary). Przegląd Geologiczny, 56: $912-920$.

Dudek, A., 1980. The crystalline basement block of the Outer Carpathians in Moravia: Bruno-Vistulicum. Rozpravy ČeskoSlovenské Akademie Věd, Řada Matematicko-přírodních Věd, 90: 1-85.

Finger, F., Hanžl, P., Pin, C., Quadt, A., Steyrer, H.P., 2000. The Brunovistulian: Avalonian Precambrian sequence at the eastern and of the Central European Variscides? Geological Society Special Publications, 179: 103-112.

Franke, W., Żelaźniewicz, A., 2000. The eastern termination of the Variscides: terrane correlation and kinematic evolution. Geological Society Special Publications, 179: 63-86.
Gładysz, J., Jachowicz, M., Piekarski, K., 1990. Palaeozoic acritarcha from the Siewierz vicinity (northern margin of the Upper Silesian Coal Basin) (in Polish with English summary). Geological Quarterly, 34 (4): 623-646.

Gradstein, F.M., Ogg, J.G., Schmitz, M.D., Ogg, G.M., 2012. The Geologic Time Scale, 2. Elsevier.

Habryn, R., Buła, Z., Nawrocki, J., 2014. The Kraków sector of the Kraków-Lubliniec tectonic zone in the light of data obtained from new boreholes of Trojanowice 2 and Cianowice 2 (in Polish with English summary). Biuletyn Państwowego Instytutu Geologicznego, 459: 45-60.

Jachowicz, M., 2005. Ordovician acritarchs from the Upper Silesian Block (in Polish with English summary). Przegląd Geologiczny, 53: 756-762.

Jachowicz, M., Přichystal, A., 1997. Lower Cambrian sediments in deep boreholes in south Moravia. Věstník Českého Geologického Ústavu, 72: 329-332.

Jachowicz-Zdanowska, M., 2010. Palynology of the Lower Cambrian of the Upper Silesian Block and of the Precambrian of the Małopolska Block, Kraków region (in Polish). In: Materiały Konferencji - „Prekambr i paleozoik regionu krakowskiego” (in Polish). Kraków, listopad 2010. Państwowy Instytut Geologiczny, Warszawa: 67-92.

Jachowicz-Zdanowska, M., 2013. Cambrian Phytoplankton of the Brunovistulicum - taxonomy and biostratigraphy. Polish Geological Institute Special Papers, 28.

Jureczka, J., Dopita, M., Gałka, M., Krieger, W., Kwarciński, J., Martinec, P., 2005. Geological Atlas of Coal Deposits of the Polish and Czech Parts of the Upper Silesian Coal Basin 1:200 000. Państwowy Instytut Geologiczny and Ministerstwo Środowiska, Warszawa.

Kalvoda, J., Leichmann, J., Bábek, O., Melichar, R., 2003. Brunovistulian terrane (Central Europe) and Istanbul Zone (NW Turkey): Late Proterozoic and Paleozoic tectonostratigraphic development and paleogeography. Geologica Carpathica, 54: 139-152.

Kalvoda, J., Bábek, O., Fatka, O., Leichmann, J., Melichar, R., Nehyba, S., Spacek, P., 2008. Brunovistulian terrane (Bohemian Massif, Central Europe) from late Proterozoic to late Paleozoic: a review. International Journal of Earth Sciences, 97: 497-518.

Kotas, A., 1972. The marine sediments of the Upper Carboniferous, and their transition into the productive deposits of the Upper Silesian Coal Basin (in Polish with English summary). Prace Instytutu Geologicznego, 61: 297-307.

Kotas, A., 1982. Zarys budowy geologicznej Górnośląskiego Zagłębia Węglowego (in Polish). Przewodnik 54 Zjazdu Polskiego Towarzystwa Geologicznego, Sosnowiec. Wyd. Geol., Warszawa: 45-72.

Kotas, A., 1985. Uwagi o ewolucji strukturalnej Górnośląskiego Zagłębia Węglowego. In: Tektonika Górnoślaskiego Zagłębia Węglowego (ed. J. Trzepierczyński) (in Polish). Materiały Konferencji Naukowej, Sosnowiec: 17-46. Wyd. Uniw. Śląskiego, Katowice. 
Kowalczewski, Z., 1990. Coarse-grained Cambrian rocks in central south Poland (lithostratigraphy, tectonics, paleogeography) (in Polish with English summary). Prace Państwowego Instytutu Geologicznego, 131: 1-82.

Leichmann, J., Kapinus, A., Pivnička, L., Weber, R., 2006. Želetice Group: very low-grade Palaeozoic sequence at the base of Moravicum, Czech Republic. Journal of the Czech Geological Society, 51: 189-199.

Moryc, W., Heflik, W., 1998. Metamorphic rocks in the basement of the Carpathians between Bielsko-Biała and Cracow. Geological Quarterly, 42 (1): 1-14.

Oberc-Dziedzic, T., Klimas, S., Kryza, R., Fanning, C.M., 2001. SHRIMP zircon geochronology of the Neoproterozoic Strzelin gneiss: evidence for the Moravo-Silesian zone affinity of the Strzelin massif, Fore-Sudetic block, SW Poland. Geolines, 13: 96-97.

Oberc-Dziedzic, T., Klimas, S., Kryza, R., Fanning, C.M., 2003. SHRIMP U-Pb zircon geochronology of the Strzelin gneiss, SW Poland: evidence for a Neoproterozoic thermal event in the Fore-Sudetic block, Central European Variscides. International Journal of Earth Sciences, 92: 701-711.

Otava, J., Hladil, J., Galle, A., 1994. The age of the Andelska Hora Formation: new facts and their possible interpretation (in Czech). Geological Research in Moravia and Silesia (Brno), 1: 52-56.

Orłowski, S., 1975. Lower Cambrian trilobites from Upper Silesia (Goczałkowice borehole). Acta Geologica Polonica, 25: 377-383.

Pacześna, J., 2005. Środowiska sedymentacji dolnokambryjskich osadów bloku górnośląskiego (in Polish). Przewodnik 76 Zjazdu Polskiego Towarzystwa Geologicznego, Rudy k/Rybnika. Warszawa: 90-99.

Pacześna, J., 2014. The facies development of Terreneuvian deposits in the eastern part of the Upper Silesian Block (in Polish with English abstract). Biuletyn Państwowego Instytutu Geologicznego, 459: 133-146.

Pacześna, J., Poprawa, P., 2001. Architektura facjalna, stratygrafia sekwencji i subsydencja dolnokambryjskiego basenu bloku górnośląskiego (in Polish) (22/2002). Narodowe Archiwum Geologiczne, Warszawa.

Piekarski, K., Szymański, B., Wielgomas, L., 1985. A new Ordovician stratigraphic reference point in the vicinities of Myszków (in Polish with English summary). Przegląd Geologiczny, 35: 501-503.

Poprawa, P., 2006. Neoproterozoic break-up of the supercontinent Rodinia/Pannotia recorded by development of sedimentary basins at the western slope of Baltica (in Polish with English summary). Prace Państwowego Instytutu Geologicznego, 186: 165-188.

Siewniak-Madej, A., Jeziorowska, M., 1978. Micropaleontological-conodont studies performed on samples from the BM152 borehole (in Polish). Archiwum Instytutu Geologii i Surowców Mineralnych AGH, Kraków.

Vavrdová, M., Mikuláš, R., Nehyba, S., 2003. Lower Cambrian siliciclastic sediments in southern Moravia (Czech Republic) and their paleogeographical constraints. Geologica Carpathica, 54: $67-79$

Żelaźniewicz, A., Buła, Z., Fanning, M., Seghedi, A., Żaba, J., 2009. More evidence on Neoproterozoic terranes in Southern Poland and southeastern Romania. Geological Quarterly, 58 (1): 93-124.

Żelaźniewicz, A., Aleksandrowski, P., Buła, Z., Karnkowski, P.H., Konon, A., Oszczypko, N., Ślączka, A., Żaba, J., Żytko, K., 2011. Regionalizacja tektoniczna Polski (in Polish). Komitet Nauk Geologicznych PAN, Wrocław. 